\title{
Hugh Popenoe Eulogy ${ }^{1}$
}

\section{Francille M. Firebaugh ${ }^{2}$}

Hugh was born in 1929 in Tela, Honduras, and after his mother, Dorothy, died in 1933, he spent the next 10 years in Silver Spring, Maryland, making frequent visits to Antigua Guatemala. When he was 13 years old, he and his sisters moved to Honduras where their father, Wilson Popenoe, was beginning the Escuela Agrícola Panamericana (EAP). Today, the second song you will hear was a favorite of Hugh's, from the family's early time in Honduras.

Hugh earned his undergraduate degree from the University of California at Davis in 1951 with a major in irrigation and worked in Thailand for a year as a soil scientist. When he first saw water buffalo in a rice paddy there, he thought the animals "would be perfect to clear weed-choked waterways in Florida and the Southeast." He was drafted and served two years in the Army Corps of Engineers. Hugh completed his $\mathrm{Ph} . \mathrm{D}$. at the University of Florida, with research on the effects of shifting cultivation on basic soil properties near Lake Isabal in Guatemala.

His career was spent at the University of Florida teaching in the areas of soils and water management, botany, agronomy, and geography, and his research focused on tropical land management systems for small stakeholders, with an emphasis on biodiversity and minimum use of industrial inputs. In more recent years, Hugh taught ethnoecology, with graduate students developing and caring for an ethnoecology garden on the campus that they are now naming for him.

After directing the Caribbean Research Program, Hugh became Director of the Center for Tropical Agriculture at University of Florida. His steadfast commitment to and enjoyment of teaching led to his being named "Professor of the Year in Agriculture" in 1964. He directed the Florida Sea Grant College from 1971-1978, chairing the Council of Sea Grant Directors during that time. Hugh took justifiable pride in his more than 300 graduate students. Attesting to his impact on the training and professional development of students, Hugh received the first Charles B. Heiser, Jr. Mentor Award in 2009 from the Society for Economic Botany.

I met Hugh when he chaired the Joint Committee on Agricultural Research of the Board of International Food and Development and I was a member of the Joint Committee on Agricultural Development. The two committees merged and we co-chaired the combined committee from 1985 to 1987 -an easy way to make or break a friendship! Fortunately it cemented ours, founded on mutual respect. In 1994, I became a member of the Zamorano Board and I am sure that Hugh played an important role in my nomination.

Hugh served on the Board of Science and Development of the National Research Council (NRC) and he was very active in their publications programmy favorite was Lost Crops of the Incas. Hugh's national and international reputation was demonstrated by his membership on the National Science Foundation International Advisory Committee.

Hugh's early impression of water buffalo led to his importing water buffalo from Guam and Trinidad in the 1970s. The herd flourished under his husbandry, growing to 800 in size, the largest in North America in the 1990s. He was awarded the Science Pioneer Prize of the Egyptian Veterinary Association of Buffalo

\footnotetext{
${ }^{1}$ Gardner Chapel, Zamorano University, Honduras, November 11, 2011.

${ }^{2}$ Francille Firebaugh became Dean of the College of Human Ecology at Cornell University in 1988; she is the seventh person to hold the title of Dean in the almost 70 year history of the college. Dean Firebaugh received a Ph.D. degree from Cornell in 1962. She returned to Cornell after 26 years at Ohio State University where she gained a reputation as a seasoned administrator. She was Vice Provost for International Affairs at Ohio State at the time of her Cornell appointment. Teaching and consultancies have taken her to Afghanistan, Egypt, India, and Malaysia. In 1988, Phi Beta Delta, an honor society for international affairs, awarded her its first Faculty Award for Outstanding Accomplishments. She is listed in Who's Who of American Women and in Who's Who in America. Dean Firebaugh is a specialist in the area of family resource management, the author or co-author of many scholarly articles, and co-author of two books. She has served on the Zamorano Board since 1993. Email f.firebaugh@gmail.com
}

DOI: $10.5377 /$ ceiba.v52i2.1745 
Development. He was generous with selling and donating animals for projects, including aquatic weed management. He and Betty regularly prepared many pounds of meat for a Miami restaurant and many of us can remember the buffalo jerky he brought to Board meetings.

From Betty, I learned that Hugh was an avid fisherman who was a great dancer, and often said that all he wanted was enough money to buy the next book for his library; he loved poetry and Latin American art; he had no interest in sartorial splendor and wore one of three ties-skinny, medium, wide-depending on the year's fashion.

Hugh most recently served as an active Emeritus member of the Zamorano Board of Trustees, following his long-time membership and stint as Chairman. Throughout his tenure on the Board, Hugh insisted on upholding the Zamorano curriculum quality, persevering in his staunch support of learning by doing, maintaining rigorous standards for faculty and administrators, and continuing a legacy of access to Zamorano for students limited means. In recent years, Hugh led the charge for Zamorano to work with indigenous students in leadership development. His financial and intellectual support for the effort will continue to inspire and prod us to do more.

Hugh was a Trustee of the International Foundation for Science whose purpose is to strengthen the capacity of developing countries to conduct research on the sustainable management of biological resources, and was a founding board member of the Organization for Tropical Studies. He was a Fellow of the Soil Science Society of America, the American Society of Agronomy, the American Association for the Advancement of Science, and the American Geographical Society.

Hugh and his sister, Dr. Marion Popenoe de Hatch, donated their ancestral colonial home in Antigua, Guatemala, built in 1636, to the Universidad Francisco Marroquin to preserve the colonial heritage of Latin America. With an abiding interest in preservation, Hugh was a supporter of the Legacy Institute for Nature and Culture and the Conservation Trust of Florida.

We extend our sympathy to Hugh's survivors Betty Haeseker, Marion and Sally Popenoe, and several nieces and nephews.

We will miss Hugh, a teacher with an ever inquisitive mind and broad interests, a scientist, a quintessential raconteur, an early riser- those of us staying at Casa Popenoe could never arrive at breakfast in CEDA before he did. Hugh, a close personal friend with unbounded dedication to Zamorano, we will miss you.

Submitted for publication on June 1, 2012.

Accepted for publication on October 29, 2012. 